\title{
Improving EFL Students' Competencies in Writing Procedure Texts through the Process Approach
}

\author{
Muhammad Lukman Syafii \\ Universitas Muhammadiyah Ponorogo, Indonesia \\ muhammadlukmansyafii@umpo.ac.id
}

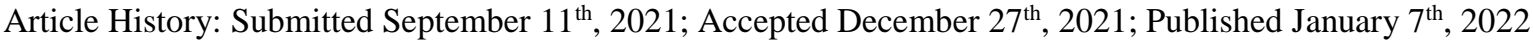

\begin{abstract}
This research aims at improving learners' competencies in writing procedure texts through a process approach. First-year students do not demonstrate sufficient mastery of writing skills. Therefore, to overcome this matter, the investigator used classroom action research. The design of the research was action research which was composed of four phases, specifically planning the action, application, observation of the action, and reflection on the action. The subject of the research was the first-year class consisting of 29 students of MTs Al-Islam Joresan Mlarak Ponorogo. Four instruments were employed to gather the data, i.e. observation checklist, field notes, questionnaire, and students' writing test. The finding of the research indicated that Cycle 1 has not fulfilled the criteria of success. Related to the first criterion, $70 \%$ of the learners did at minimum $64.3 \%$ of the activities ( 9 activities out of 14 activities) in the observation checklist, and in Cycle 2 showed $78.5 \%$ has fulfilled the criteria of success. Concerning the second criterion $65.5 \%$ (19 learners) of the learners, gained a score on a par or more than 60, the research has fulfilled the criteria of success but required rectifying. In Cycle 2, the research finding showed $95 \%$ of the learners ( 28 learners), the research has fulfilled the criteria of success. Concerning the final criterion, at least $82 \%$ of the learners (24 learners) served positive reactions to the application of the process approach as shown by the outcome of the questionnaire, observation checklist, field notes, and students' writing test.
\end{abstract}

Keywords: writing competencies; procedure texts; process approach

Abstrak. Penelitian ini bertujuan untuk meningkatkan kompetensi siswa dalam menulis teks prosedur melalui pendekatan proses. Siswa tahun pertama tidak menunjukkan penguasaan keterampilan menulis yang cukup. Oleh karena itu, untuk mengatasi masalah tersebut, peneliti menggunakan penelitian tindakan kelas. Desain penelitian ini adalah penelitian tindakan yang terdiri dari empat tahap, yaitu perencanaan tindakan, penerapan, pengamatan tindakan, dan refleksi tindakan. Subjek penelitian ini adalah siswa kelas satu yang terdiri dari 29 siswa MTs Al-Islam Joresan Mlarak Ponorogo. Empat instrumen digunakan untuk mengumpulkan data, yaitu daftar periksa observasi, catatan lapangan, angket, dan tes menulis siswa. Hasil penelitian menunjukkan bahwa Siklus 1 belum memenuhi kriteria keberhasilan. Terkait dengan kriteria pertama, 70\% peserta didik melakukan minimal 64,3\% tindakan (9 kegiatan dari 14 kegiatan) dalam daftar periksa observasi, dan pada Siklus 2 menunjukkan 78,5\% telah memenuhi kriteria keberhasilan. Untuk kriteria kedua 65,5\% (19 peserta didik) peserta didik, memperoleh nilai setara atau lebih dari 60, penelitian telah memenuhi kriteria keberhasilan tetapi perlu diperbaiki. Pada Siklus 2, hasil penelitian menunjukkan 95\% peserta didik (28 peserta didik), penelitian telah memenuhi kriteria keberhasilan. Untuk kriteria akhir, setidaknya 82\% peserta didik (24 peserta didik) memberikan reaksi positif terhadap penerapan pendekatan proses seperti yang ditunjukkan oleh hasil angket.

Kata kunci: kompetensi menulis; teks prosedur; pendekatan proses 


\section{INTRODUCTION}

English as a foreign language in Indonesia is regarded to be a necessary subject the learners should master (Mustafa, Kirana, \& Bahri Ys, 2016). Regarding this rationale, it has been determined that English gets one of the obligatory subjects that have to be instructed as a foreign language, mainly to junior high school learners (Kirkpatrick \& Sussex, 2012). The School-Based Curriculum said that the aim of teaching English in junior high school is that the learners have to be able to expand their interactive skills both in a written and spoken shape to reach a functional literacy degree (Mattarima \& Hamdan, 2011). This implies that teaching English is referred to as expanding the four skills of English: listening, speaking, reading, and writing (Roy-Campbell, 2015). Those skills are required to achieve communicative competence since the English syllabus states that learning the English language means learning to communicate in a language (Savignon, 2017).

In contrast with speaking, writing is even harder since the specific features of written language are more complicated than those of spoken language (Biber et al., 2011). The complications reside in the utilization of standard language and the level of formality. Shehadeh (2011) states that Writing is considered the most difficult skill for foreign language students to master, because it involves several parts that need to be considered while students are writing, for example, content, organization, use of vocabulary, use of grammar, and mechanical considerations, for example, spelling and punctuation. In addition, when the writer is writing, he/she should also consider the needed factors like the forum, the pitch, and the purpose of writing itself (Alfaki \& الفكى, 2015).

Based on the researcher's observations on the teaching writing in classroom activities in this school, the English teachers concentrate their teaching too much on grammatical aspects and not a lot on the result of writing. This implies that several English teachers just sometimes work out the teaching of writing. Starting with just clarifying the topic that will be written by students while students listen to clarification. Students are then asked to recite low writing within a certain period that is distributed without using several examples. The teacher expects students' writing products without providing additional instructions. Finally, students submit their work to the teacher. This monotonous and effective teaching and learning activity creates a situation where writing is considered a boring activity and wastes a lot of time. As a result, students are not motivated to write essays. In the absence of guidance and feedback, most of the students complained that writing assignments were too difficult for them. Ratnaningsih (2016) states that writing is the hardest skill to dominate due to its trouble in resulting setting and interpreting opinions into a readable text.

The difficulties dealing with writing as mentioned above are also faced by the students of the school where the researcher taught. Based on the researcher's personal experience when he instructed at the school, it is set up that the competence of the learners in four language skills mainly writing skills is still far away from the curriculum objective. The competence of the learners to declare and set their opinions into the right regulation of the sentences to get the right paragraph is still poor. This can also be seen from the results of the preliminary studies conducted. The average score of students in writing is 4.50 while the standard of learning achievement is 60 .

The lack of student achievement in writing was caused by these factors, that is, students could not express and express their opinions in written form. There were many errors in content, organization, and use of language. It was very difficult for them to start writing because of their limited vocabulary and their inadequate knowledge of grammatical structures. The limited vocabulary made them unable to respond well to the teacher's instructions. They just waited for the teacher's help in translating the instructions into Indonesian, the students lacked practice. The time allocated to English required four 
contact hours a week of forty minutes each to teach all English skills. There were twenty-nine students in grade VII. There was not enough time to properly guide all students. Twenty students had low motivation and attention in the writing class because the activities provided by the teacher were less interesting and carried out in a monotonous manner. The strategies used by the teacher were not too varied so that students felt worn during the teaching and learning process. Teachers tended to assign students to write a paragraph and wait for their writing to be evaluated without guiding them from beginning to end. As a result, students could not produce good writing products.

With the above factors, the researcher recognized that the main cause of the unsatisfying result of the student's writing performance is not merely because of the poor competence of the learners in writing, but also the students' lack of practice. In addition, the appropriate strategy used by the teacher in the teaching and learning process influences the learners' motivation in a writing activity (Duijnhouwer, Prins, \& Stokking, 2012).

About the problems faced by the learners of this school in writing, the teacher of this school attempts to obtain a breakthrough to succeed in the matters. The likely breakthrough is that the teacher ought to utilize a suitable strategy that can decrease the learners' troubles so that the student's competence in writing can be rectified.

The researcher is appealed in implementing the process approach as a breakthrough for the learners' problems in writing. This approach is selected based on its efficacy in engaging the learners entirely in the process of resulting their part of writing correctly from the beginning to the end. It enables the learners to finish their composition stage by stage until they arrive at the last concept thru four phases specifically: prewriting, drafting, revising, and editing (Biggam, 2018).

In the early stage of writing, the students have the chance to declare and set their opinions without worrying too much about spelling and grammar. They can change, add, or delete anything in their draft at the next stages until their draft becomes the final version. In addition, they have feedback from their classmates and the teacher which will be used as a reference to further revise their draft (Lam, 2010). Therefore, the four stages are needed by the students.

In the reality, the researcher implemented the process approach in rectifying the learners' competence in writing. The process approach is selected as the strategy because there are a lot of gains that the learners may obtain. Ouellette et al., (2013) assert that in this approach the learners seem as the maker of the language. It is likely to occur because the learners are required to be engaged in the stages in making a part of the written result. Other realities promote the gains of facing a process approach to overcome the learner's maters in writing (Palloff \& Pratt, 2013).

The state of the art and the novelty are that this Process Approach is different from the above research. In this activity, the researcher together with his collaborator designed the teaching strategy by developing a model of the Proses Approach in teaching reading.

Eventually, the investigator implemented the process approach in the first-year learners to rectify the learners' competence in writing procedure texts so that their creations can be more apprehensible. The investigator is going to make an equilibrium between product writing and process learning because it is not possible to get the learners' progress sans finding out their result. By the finish of the implementation of this research, it is expected that thru the process approach, the learners are to rectify their expertise in writing procedure texts. 
As the aim of the study is to improve the learners' competence in writing procedure texts of the first grade of this school through the process approach. The significance of this study is expected to contribute a useful strategy to the English teachers and other researchers. In addition, Hosni (2014) writes that the development of writing skills that focuses on the communicative aspect of language does not suggest that grammar exercise is unnecessary. It means that grammar is also important for the students to master. Moreover, Zaid (2011) explains that writing is a complicated process allowing writers to cruise mind and notion, and make them noticeable and substantial. When though are written down, thoughts can be tested, reconsidered, appended to, readjusted, and altered. The research gap in his study is that the model provided to the learners should be clarified in detail so that the learners can adhere to the model perfectly.

\section{METHOD}

\section{Research Design}

The design of this study belongs to a Classroom Action Research (CAR). The choice of this design is to improve the students' ability in writing procedure texts through the process approach.

\section{Technique of Data Collection}

To gather the data needed, there were four types of research instruments the investigator developed, namely observation checklist, field notes, the learners' writing test, and questionnaire.

\section{Technique of Data Analysis}

The procedures of data analysis were with the data. The data on the learners' participation at every step of the process approach that was gained thru an observation checklist was calculated in percentage using a frequency base. The following formula was used to obtain the percentage of the activities done by the students:

$$
\ldots \ldots \%=\frac{\text { The number of activities done by the students }}{\text { The total number of the listed activities (14) }} \times 100 \%
$$

\section{Setting and Subjects of the Study}

This action research is conducted at MTs Al-Islam Joresan, Mlarak, Ponorogo. The subjects of the study are first-year students. This class consists of 29 students (16 males and 13 females) who come from different families and educational backgrounds. Most of the students' parents are farmers and the rest are civil servants, traders, teachers, and uncertain workers.

\section{Procedures of Data Collection and Data Analysis}

The first instrument was the observation checklist employed by the collaborator in every cycle to record the learners' activities during the teaching and learning process in writing procedure texts through the process approach.

The second instrument was field notes. The teacher utilized the field notes in every cycle in the application of the process approach in writing procedure text. This instrument was used to note 'good point and points to be rectified from the learners and the teachers which took place during the implementation of the study in the classroom that may not be encompassed in the observation 
checklist such as the learners' reactions to the application of each stage of process approach in writing. How was this analyzed?

The third instrument was the students' writing test. The learners' writing test was collected after the application of the process approach in writing procedure texts.

The last instrument was a questionnaire. The researcher makes use of the questionnaire to obtain the data on the students' reactions to the implementation of the process approach in their writing class. The questionnaire was provided to the learners after the implementation of the process approach in writing completely. The questionnaire consisted of 9 questions.

The questionnaire was tried out to know whether or not the students can understand the statement easily. At first, the terms such as process approach in writing, prewriting, drafting, revising, and editing was used. Then, it was suggested that the terms be translated into Indonesia to make the students easy to understand the statement. The questionnaire is provided in Table 1.

Table 1 Questionnaire and Students' Responses

\begin{tabular}{|c|c|c|c|c|c|c|}
\hline \multirow{2}{*}{$\begin{array}{l}\text { No } \\
1\end{array}$} & \multicolumn{2}{|c|}{ Question } & \multicolumn{4}{|c|}{ Answers } \\
\hline & $\begin{array}{l}\text { Do I enjoy } \\
\text { learning }\end{array}$ & strongly agree & b. agree & c. less agree & d. disagree & $\begin{array}{l}\text { e. strongly } \\
\text { disagree }\end{array}$ \\
\hline \multirow{4}{*}{2} & English? & 7 & 18 & 4 & 0 & 0 \\
\hline & & $24.14 \%$ & $62.06 \%$ & 13.80 & & \\
\hline & $\begin{array}{l}\text { I think } \\
\text { learning }\end{array}$ & a. strongly agree & b. agree & c. less agree & d. disagree & $\begin{array}{l}\text { e. strongly } \\
\text { disagree }\end{array}$ \\
\hline & English is fun. & 8 & 13 & 8 & 0 & 0 \\
\hline \multirow{3}{*}{3} & & $27.58 \%$ & $44.83 \%$ & $27.58 \%$ & & \\
\hline & $\begin{array}{l}\text { Do you like to } \\
\text { write in }\end{array}$ & a. really like & b. I like it. & c. less like & d. I dislike & $\begin{array}{l}\text { e. strongly } \\
\text { dislike }\end{array}$ \\
\hline & English? & 3 & 11 & 13 & 2 & 0 \\
\hline \multirow{4}{*}{4} & & $10.34 \%$ & $37.93 \%$ & $44.83 \%$ & $6.90 \%$ & \\
\hline & $\begin{array}{l}\text { Before } \\
\text { writing do you }\end{array}$ & a. strongly agree & b. agree & c. less agree & d. disagree & $\begin{array}{l}\text { e. strongly } \\
\text { disagree }\end{array}$ \\
\hline & $\begin{array}{l}\text { want the } \\
\text { teacher to give }\end{array}$ & 15 & 13 & 1 & 0 & 0 \\
\hline & $\begin{array}{l}\text { you } \\
\text { instructions } \\
\text { first in writing } \\
\text { to make it } \\
\text { easier for } \\
\text { you? }\end{array}$ & $51.72 \%$ & $44.83 \%$ & $3.44 \%$ & & \\
\hline \multirow[t]{3}{*}{5} & $\begin{array}{l}\text { Pre-writing } \\
\text { activities (pre- }\end{array}$ & a. strongly agree & b. agree & c. less agree & d. disagree & $\begin{array}{l}\text { e. strongly } \\
\text { disagree }\end{array}$ \\
\hline & $\begin{array}{l}\text { writing) make } \\
\text { it easier for }\end{array}$ & 9 & 12 & 8 & 0 & 0 \\
\hline & $\begin{array}{l}\text { me to get } \\
\text { ideas about } \\
\text { what I will } \\
\text { write. }\end{array}$ & $31.03 \%$ & $41.37 \%$ & $27.68 \%$ & & \\
\hline
\end{tabular}




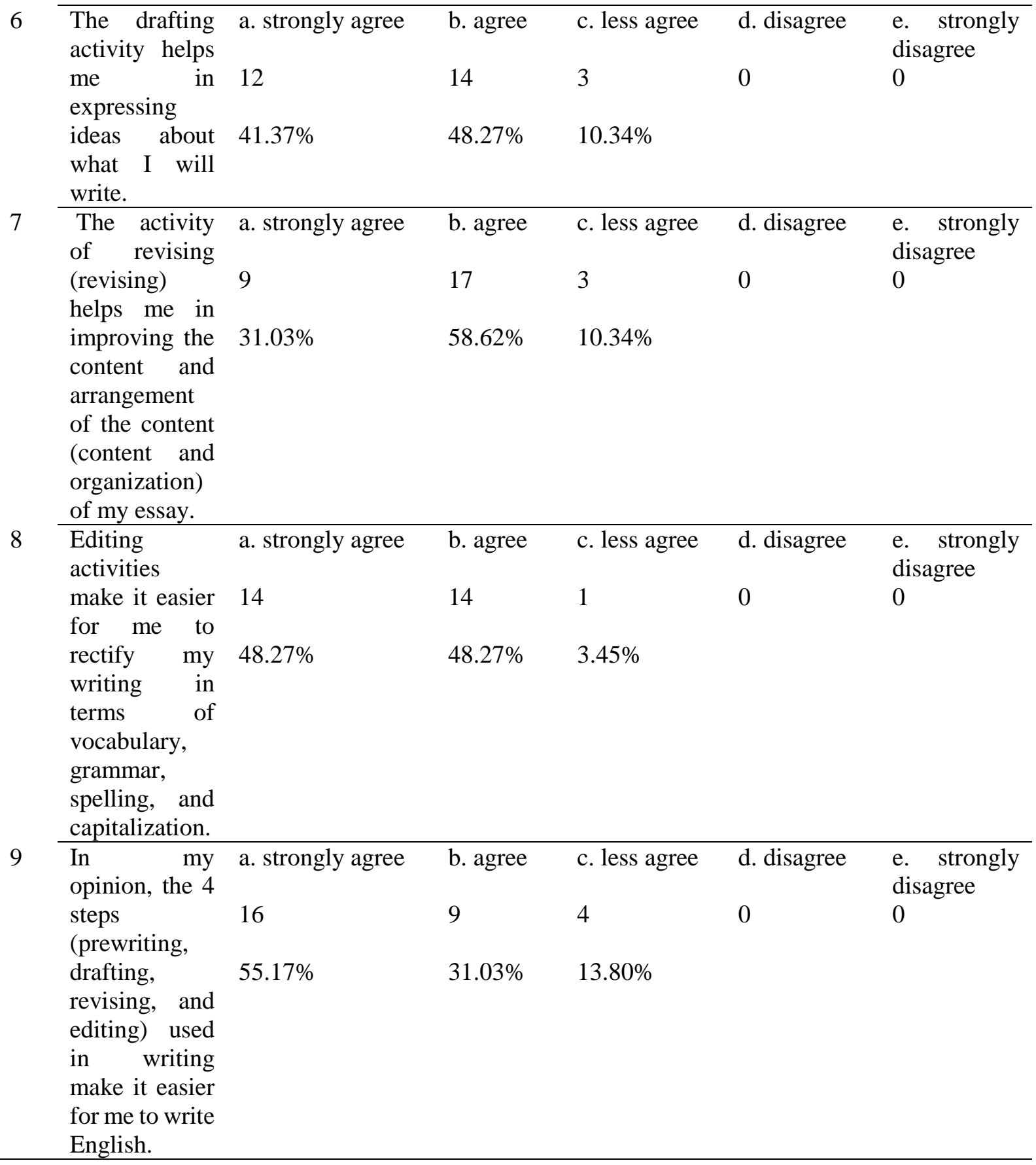

Table 1 indicates that there were $55.17 \%$ of students chose number 9 which was the most choice of the students who strongly agreed with the statement. Whereas, the two students who disagreed with questionnaire number 3 were $6.90 \%$ of the students. This questionnaire had good responses to the students.

Table 2 The Description of the Research Instruments and the Variables

\begin{tabular}{|c|c|c|c|}
\hline No & Instruments & Data & Variable \\
\hline 1 & $\begin{array}{l}\text { Observation } \\
\text { checklist }\end{array}$ & $\begin{array}{l}\text { The student's } \\
\text { participation in the } \\
\text { teaching and } \\
\text { learning process }\end{array}$ & $\begin{array}{l}\text { The learners' activities at every stage of the } \\
\text { process approach. They are prewriting, } \\
\text { drafting, revising, and editing }\end{array}$ \\
\hline
\end{tabular}




2 Fieldnotes $\begin{aligned} & \text { The student's The 'good' and 'things to be improved' from } \\ & \text { participation in the the teacher and the students } \\ & \text { teaching and } \\ & \text { learning process }\end{aligned}$
3 Students' $\begin{aligned} & \text { The learners' The leaners' product at each stage of the } \\ & \text { progress at each process approach and students' final products. } \\ & \text { stage of the process }\end{aligned}$
$\begin{aligned} & \text { approach } \\ & \text { Questionnaire }\end{aligned}$
$\begin{aligned} & \text { The learners' The student's feelings about the application of } \\ & \text { responses to the the process approach in their writing and the } \\ & \text { application of the effects of the process approach for their } \\ & \text { process approach in writing. } \\ & \text { writing }\end{aligned}$

To know the percentage of the students who do $70 \%$ of the listed activities, the following formula is used:

$$
\ldots \ldots \%=\frac{\text { The number of the students who do } 70 \% \text { of the activities }}{\text { The total number of students }(29)} \times 100 \%
$$

While the data gained from the learners' final product were anatomized by utilizing the analytic scoring rubric. The procedure is that each aspect of student writing is given a score ranging from 15 , the score for each aspect is then converted to get a conversion score based on its weight, and the converted scores are added up to get the student's final score.

In this study, inter raters employed it to score the students' final products. The intention of doing this is to avoid subjectivity and to know the reliability of the score. To estimate the reliability of the 2 raters, a formula of Pearson Product Moment was used (Ltd, 2013). The formula is as follows.

$$
\mathrm{r}-\mathrm{xy}=\frac{\sum(\mathrm{X}-\mathrm{Y})(\mathrm{Y}-\mathrm{Y})}{\mathrm{N} \mathrm{Sx} \mathrm{Sy}}
$$

Where:

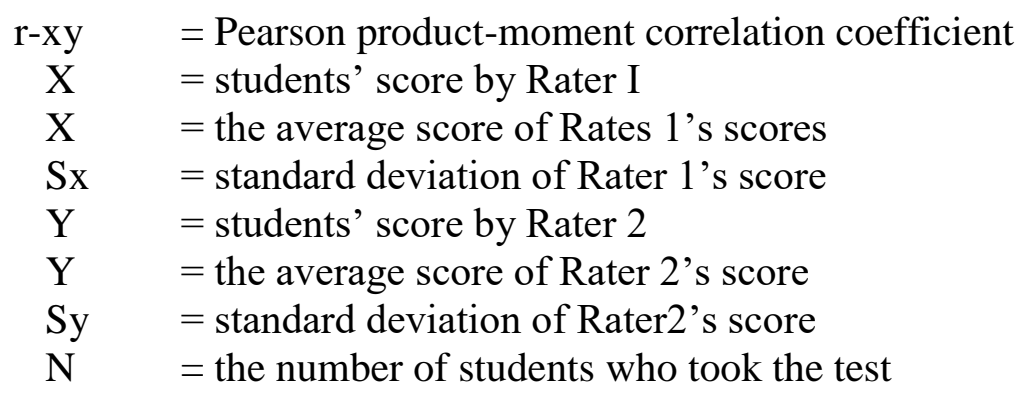

The data on the students' reaction to the implementation of the process approach gained from the questionnaire were analyzed by calculating it in percentage by using a frequency base. The formula is:

$\ldots \%=\underline{\text { Number of students choosing certain option for each statement }} \times 100 \%$

Total number of the students (29) 
The analysis of the data obtained from field notes and learners' final writing was in the form of description and cross-checked to the data from other instruments.

After the process of data analysis was finished, it is time for the researcher to have a reflection. Reflection is the most important step of action research. Reflection was meant to assess the influence of the action that has been implemented on the learners' competence to write in procedure texts. For this rationale, the product of the data analysis was verified to the criteria of success destined to conclude. If all the criteria of success have been fulfilled, the action is quitted and if one of the criteria of success is not yet fulfilled, the research is kept on to the next cycle by going over and rectifying the plan. The rectification and refinement are concentrated on the pertinent criteria that are not yet fulfilled in Cycle I.

\section{The Criteria of Success}

The criteria play an important role in this research. They indicate to the researcher the type of data to be collected and when to stop the research. This action research is said to be successful if it meets the following criteria.

First, $70 \%$ of students or more participate in the teaching and learning process. Students are considered to participate in the teaching and learning process $70 \%$ (20 of 29 students) of students carry out $70 \%$ of the activities listed in the student observation list in the application of the process approach. The activities are generating, selecting, sorting ideas (at the pre-writing stage), pouring ideas into paper, compiling ideas into drafts (at the drafting stage), revising the draft using revision guidelines in terms of content and organization, after discussing with the teacher (at the revision stage). ), and edit drafts using editing guidelines in terms of spelling, punctuation, capitalization, grammar, and vocabulary (at the editing stage). To find out whether students participated or not in the writing process, collaborative researchers and teachers used an observation checklist. The observation checklist contains activities that students must do at each stage of the process approach.

Second, at least $50 \%$ of the final product students obtained a final score equal to or more than 60 in the analytic scoring rubric. Students are considered successful if they can achieve a final score of at least 60 in the analytical assessment rubric. The consideration of this score is the minimum passing grade of English in schools determined by the English teacher by considering several aspects: the complexity of the material, school facilities, and student absorption. The criteria of success for English is 60 out of 100. It means $60 \%$ of the maximum score. The maximum score in the analytic scoring rubric is 100 and $60 \%$ is 60 .

Lastly, $70 \%$ of students or more had a positive response to the application of the process approach to their writing class. The study was considered successful if $70 \%$ of students or more had a positive response to the application of the process approach to their writing class. This means that students choose the expected option (strongly agree/agree) for the answers to each item in the questionnaire. The students' answers indicated that they were happy with applying the process approach in their writing class and felt that the process approach in writing was useful and could help them produce better writing. To determine student responses to the application of the process approach, a questionnaire consisting of 12 questions. 


\section{FINDINGS AND DISCUSSIONS}

\section{Research Findings of Cycle 1}

In Cycle I the data was collected at the first graders of school. The number of students was 29 students. The instruments utilized were the observation checklist, field notes, writing prompts, and the questionnaire. The presentation of the findings of the research is by the criteria of success specified, i.e. the learners' inclusion in the application of the process approach in writing, the learners' last results, and the learners' responses to the application of the process approach.

To get the data on the students' inclusion in the teaching and learning process, the investigator utilized two instruments namely the observation checklist and field notes. The observation checklist consisted of 14 activities in 4 stages of the process approach in writing procedure texts. At the prewriting stage, there were 4 activities, i.e. answering the teachers' questions, discussing, paying attention to a model of procedure texts, exploring their ideas, and ordering ideas. At the second stage, drafting, the students should arrange their ideas into a rough draft. At the revising stage, the activities were revising the draft about content and organization. In the last stage, editing, the activities dealt with editing the grammar, vocabulary, spelling, capitalization, and punctuation of the draft.

For the data on the learners' inclusion in the teaching and learning process, the criteria of determining were $70 \%$ of the students or more do of the list activities (10 activities out of 14 activities) see Table 3.

The yield of the data analysis that was done on the frequency-count base showed that 9 activities out of 14 activities have done by the students $(64.3 \%)$ in Cycle I. Table 3 shows the students' participation in each stage of the process approach in general.

Table 3 The Students' Participation in Each Stage of the Process Approach.

\begin{tabular}{|c|c|c|c|c|}
\hline Meeting & $\begin{array}{l}\text { Instruction } \\
\text { al Process }\end{array}$ & Activities Number & $\begin{array}{l}\text { The activities } \\
\text { are done (yes) }\end{array}$ & $\begin{array}{l}\text { The activities are } \\
\text { not done (no) }\end{array}$ \\
\hline 1 & Prewriting & $\begin{array}{l}\text { Answering the teacher's questions. } \\
\text { Discussing with their groups. } \\
\text { Paying attention to a model of } \\
\text { procedure texts. } \\
\text { Exploring their ideas, order ideas for } \\
\text { the initial draft. }\end{array}$ & $\begin{array}{l}\sqrt{ } \\
\sqrt{ } \\
\sqrt{ }\end{array}$ & $\sqrt{ }$ \\
\hline & Drafting & $\begin{array}{l}\text { Writing title, ingredients, and steps. } \\
\text { Making sentences and arranging them } \\
\text { in a rough draft based on the } \\
\text { instruction. } \\
\text { Writing their first draft. }\end{array}$ & $\begin{array}{l}\sqrt{ } \\
\sqrt{ }\end{array}$ & $\sqrt{ }$ \\
\hline 2 & Revising & $\begin{array}{l}\text { Working in groups } \\
\text { Revising their draft based on } \\
\text { guidelines of revising. } \\
\text { Revising their classmates' draft. } \\
\text { Discussing with the peer and the } \\
\text { teacher. }\end{array}$ & $\begin{array}{l}\sqrt{ } \\
\sqrt{ }\end{array}$ & $\begin{array}{l}\sqrt{ } \\
\sqrt{ }\end{array}$ \\
\hline 3 & Editing & $\begin{array}{l}\text { Rewriting a greater draft with the } \\
\text { feedback from the teacher and their } \\
\text { classmates. }\end{array}$ & $\begin{array}{l}\sqrt{ } \\
\sqrt{ }\end{array}$ & \\
\hline
\end{tabular}


Exchanging their revised draft with their peers.

Editing the grammar, spelling, punctuation, and capitalization based on the guidelines of editing.

\section{N: 29 students}

The results of the observation of students' participation in Cycle I show that the learners' involvement during the writing process achieved a fair level, that is, twenty-nine students were involved in the activity in each phase of the process approach (pre-writing, drafting, revising, and editing), the percentage of the learners' involvement during the writing activities was $64.3 \%$ ( 9 activities out of 14 activities were done by the students). In a conclusion, the final percentage for the students' participation in Cycle I was 64.3\%, meaning that the first criterion of success has not been successfully met.

Based on field notes written by the teacher, it was also found that six students remained in their group inactive, looking reluctant to mingle with the other to divide take up opinions. They did not provide a good reaction. There was something to be improved i.e. there were several learners who did not care about the teachers' clarification, several learners did not grasp the teachers' explanation, and some students were only busy borrowing the dictionary.

At the editing step, the learners found it difficult to edit their drafts as editing dealt with many features such as grammar, vocabulary, capitalization, and punctuation. The data were the samples of the mistake learners' writing, 'How to make tempe goreng'. Materials; corlander, turmeric, salt, add some woter and crush same garlic, and steps; one to cutting a bar of tempe into to slices, and to frying tempe in to hot oil. Next, they turn light brown. Then soak tempe into the spices. Frying tempe is readying to served.

Sample of the correct writing was; How to Make Fried Tempe' Materials; coriander, turmeric, salt, add some water, and crush some garlic. Steps; first, cut a bar of tempe, into slices. Second, fry tempes into hot oil until they turn light brown. Third, soak tempe into the spices, and finally, fried tempe is ready to be served.

In addition, the field notes also exposed some good points from both the student and the teacher. From the student's side, along with the implementation of this approach, the learners were accomplished their task. Besides, some students did not active in accomplishing their tasks. From the teacher's side, the teacher was hands-on in helping the students in finishing their tasks. In the teaching and learning process, he went around the groups to check whether or not the students found difficulties in doing the tasks.

To obtain the data on the learners' reactions to the implementation of the process approach in composing procedure texts, the researcher utilized questionnaires consisting of 9 statements. The statements covered 2 aspects, namely the students' feelings about the implementation of the process approach and the effects of the process approach in their writing procedure texts. Regarding the learners' reactions to the implementation of the process approach in writing procedure texts, the criteria of success state that at least $70 \%$ of the learners should give good reactions to the implementation of the process approach.

The administration of the questionnaire was conducted after the students finished writing their final products. Appointing to the result of the data analysis that was implemented based on frequency 
count, it was obtained that learners' responses were good to the implementation of the process approach in their writing class. The detailed percentage of the learners' reactions to the implementation of the process approach is presented in Table 4.

The first question asks students' opinions whether they feel happy studying English. The responses to the analysis of the questions of the students are as follows. The majority of the students $(62.06 \%)$ state their agreement that they like learning English.

Table 4 The Percentage of the Learners' Reactions to the Implementation of the Process Approach

\begin{tabular}{|c|c|c|c|c|c|c|}
\hline \multirow{2}{*}{ No } & \multirow{2}{*}{ Statement } & \multicolumn{4}{|c|}{ The students' Responses } & \multirow{2}{*}{$\begin{array}{l}\text { Total } \\
(\%)\end{array}$} \\
\hline & & $\mathbf{A}$ & B & C & D & \\
\hline 1 & I feel happy learning English & $24.14 \%$ & $62.06 \%$ & \multicolumn{2}{|l|}{$13.80 \%$} & $0 \%$ \\
\hline 2 & I think learning English is fun & $27.58 \%$ & $44.83 \%$ & \multicolumn{2}{|c|}{$\begin{array}{r}27.58 \% \\
100 \%\end{array}$} & $0 \%$ \\
\hline 3 & Do you like writing in English? & $10.34 \%$ & $37.93 \%$ & \multicolumn{2}{|c|}{$\begin{array}{l}44.83 \% \\
100 \%\end{array}$} & $0 \%$ \\
\hline 4 & $\begin{array}{l}\text { Before writing, do you want the teacher to } \\
\text { give you instructions first in writing to } \\
\text { make it easier for you? }\end{array}$ & $51.72 \%$ & $\begin{array}{l}44.83 \\
\%\end{array}$ & \multicolumn{2}{|c|}{$\begin{array}{l}3.44 \% \\
100 \%\end{array}$} & $0 \%$ \\
\hline 5 & $\begin{array}{l}\text { Pre-writing activities make it easier for me } \\
\text { to get ideas about what I will write. }\end{array}$ & $31.03 \%$ & $41.37 \%$ & \multicolumn{2}{|c|}{$27.68 \%$} & $0 \%$ \\
\hline 6 & $\begin{array}{l}\text { The activity of making a draft helps me in } \\
\text { expressing ideas about what to write. }\end{array}$ & $41.37 \%$ & $48.27 \%$ & \multicolumn{2}{|c|}{$10.34 \% 0 \%$} & $100 \%$ \\
\hline 7 & $\begin{array}{l}\text { Revising activities help me to improve } \\
\text { content and content arrangement }\end{array}$ & 31.03 & $58.62 \%$ & \multirow{2}{*}{\multicolumn{2}{|c|}{$10.34 \%$}} & $0 \%$ \\
\hline 8 & $\begin{array}{l}\text { Editing activities make it easier for me to } \\
\text { rectify my writing in terms of vocabulary, } \\
\text { grammar, spelling, and capitalization. }\end{array}$ & $51.72 \%$ & $48.27 \%$ & & & $100 \%$ \\
\hline 9 & $\begin{array}{l}\text { I think the } 4 \text { steps used in writing are easy } \\
\text { for me to write in English. }\end{array}$ & $55.17 \%$ & $31.03 \%$ & \multicolumn{2}{|c|}{$13.80 \%$} & $0 \%$ \\
\hline
\end{tabular}

$N: 29$ students

Note: A. Strongly agree, B. Agree, C. Strongly disagree, D. Disagree

The second question asks students' opinion whether 'in my opinion, studying English was interesting.' The responses to the questions of the students are as follows. The majority of the students $(44.83 \%)$ states their agreement that studying English was interesting.

The next question number third asks students' opinion whether 'Do you like to write in English?' The response to the question of the students is as follows. The majority of the students (45\%) state their disagreement that they did not like to write English. The fourth question asks students' opinion whether 'Before writing what do you like your teacher to instruct in writing?' The response to the question of the students is as follows. The majority of the students $(51.72 \%)$ state their strong agreement that they like to instruct writing. The fifth question asks students' opinion whether 'Prewriting activities make me easy in generating ideas about what to write.' The response to the question of the students is as follows. The majority of the students $(41.37 \%)$ state their agreement that prewriting activities made them easy in generating ideas in their writing. the next question asks students' opinion whether 'Drafting activities ease me in putting the ideas which I have into a rough draft.' The response to the question of the students is as follows. The majority of the students 
(48.27\%) state their agreement that drafting activities ease them in putting their ideas into the rough draft. The seventh question asks students' opinion whether 'Revising activities help me in making the content and organization of my draft better.' The response to the question of the students is as follows. The majority of the students (58.62\%) state their agreement that revising activities helped them in making the content and organization of their draft better. The eighth question asks students' opinion whether 'Editing activities facilitate me in making my draft better in terms of mechanics.' The response to the question of the students is as follows. The majority of the students $(51.71 \%)$ state their strong agreement that editing activities facilitate them in making their draft better terms of mechanics. The last question asks students' opinion whether 'In my opinion, the process approach makes me easier in English writing.' The response to the questions of the students is as follows. The majority of the students $(55.17 \%)$ state their strong agreement that the process approach makes them easier in English writing.

Finally, we could that the data obtained from the questionnaire about the students' response toward the application of the process approach has met the third criterion determined. Thus, the result of the analysis of the data obtained from the questionnaire which was intended to know the learners' reactions to the implementation of the process approach in writing indicated that the learners responded positively in the implementation of the process approach.

The data on the learners' final products were gained from the learners' writing tests. The data then were anatomized by utilizing the analytic scoring rubric giving different weighting to different aspects of writing. Besides, an inter-rater was also employed to avoid subjectivity. About the learners' last result, the criteria of success state that at minimum 50\%. The learners should achieve a score equal to or more than 60 as the minimum passing grade in the school.

The 2 raters who assessed the products were the researcher herself and her collaborator. The learners' last scores were the result of stacking up the student's 2 scores from the 2 raters and splitting the total number by 2 . The result of the analysis indicated that 23 students $(79 \%)$ obtained a score equal to or more than 60 and 6 students $(21 \%)$ got a score below 60 . The score for the former group ranged from 50-70. The details of students' score distribution in terms of content, organization, vocabulary, grammar, and mechanics in Cycle I was able to be seen in Table 4.3.

About every facet of writing, the result of the data analysis showed that, in general, the learners improved when it was appealed to their score in the precursory research and Cycle I.

In terms of content, the mean score of learners' writing was 3.18, which could be classified in the fair category. There were 9 students out of 29 students (31\% of the students) who got scores in the fair category. 20 students (69\% of the students) got a score in the poor category. It was noticed that there were not any students who were included in the very good, good, and very poor category.

Table 5 The Students Score Distribution in Terms of Contents, Organization, Vocabulary, Grammar, and Mechanic in Cycle I

\begin{tabular}{|c|c|c|c|c|c|c|c|c|c|c|}
\hline $\begin{array}{l}\text { Writing } \\
\text { Aspects }\end{array}$ & \multicolumn{2}{|c|}{ Content } & \multicolumn{2}{|c|}{$\underset{\text { on }}{\text { Organizati }}$} & \multicolumn{2}{|c|}{ Vocabulary } & \multicolumn{2}{|c|}{ Grammar } & \multicolumn{2}{|c|}{ Mechanic } \\
\hline Category & $\begin{array}{l}\text { Dist } \\
\text { ribu } \\
\text { tion }\end{array}$ & $\begin{array}{l}\text { Percen } \\
\text { tage }\end{array}$ & $\begin{array}{l}\text { Dis } \\
\text { tri } \\
\text { but } \\
\text { ion }\end{array}$ & $\begin{array}{l}\text { Perc } \\
\text { enta } \\
\text { ge }\end{array}$ & $\begin{array}{l}\text { Dist } \\
\text { ribu } \\
\text { tion }\end{array}$ & $\begin{array}{l}\text { Percen } \\
\text { tage }\end{array}$ & $\begin{array}{l}\text { Dist } \\
\text { ribu } \\
\text { tion }\end{array}$ & $\begin{array}{l}\text { Perce } \\
\text { ntage }\end{array}$ & $\begin{array}{l}\text { Dis } \\
\text { trib } \\
\text { uti } \\
\text { on }\end{array}$ & $\begin{array}{l}\text { Perc } \\
\text { enta } \\
\text { ge }\end{array}$ \\
\hline
\end{tabular}




\begin{tabular}{lllllllllll}
\hline $\begin{array}{l}\text { Very } \\
\text { good }\end{array}$ & 0 & $0 \%$ & 0 & $0 \%$ & 0 & $0 \%$ & 0 & $0 \%$ & 0 & $0 \%$ \\
$\begin{array}{l}\text { Good } \\
\text { Fair }\end{array}$ & 0 & $0 \%$ & 0 & $0 \%$ & 1 & $3.5 \%$ & 0 & $0 \%$ & 0 & $0 \%$ \\
$\begin{array}{l}\text { Poor } \\
\text { Very }\end{array}$ & 20 & $69 \%$ & 4 & $14 \%$ & 27 & $93 \%$ & 26 & $90 \%$ & 18 & $62 \%$ \\
poor & $0 \%$ & 0 & $0 \%$ & 0 & $0 \%$ & 0 & $0 \%$ & 0 & $0 \%$ \\
Total & 29 & $100 \%$ & 29 & $\begin{array}{l}100 \\
\%\end{array}$ & 29 & $100 \%$ & 29 & $100 \%$ & 29 & 100 \\
\hline
\end{tabular}

About the organization, the mean score of learners' writing was 3.07, which could be classified into the fair category. There were 4 learners (14\% of the learners) who got a score in the fair category, 25 students ( $86 \%$ of the students) got a score included in the poor category. It was noticed that there was not any student who was included in the very good, good, and very poor category.

Next in terms of vocabulary, the mean score was 2.92, which could be classified in the fair category. Only one student $(3.5 \%$ of the students) got a score in the good category, 27 students $(93 \%$ of the students) got a score included in the fair category. 1 student (3.5\% of the students) got a score included in the poor category. It was noticed that no student was included in the very good, and very poor categories.

In terms of grammar, the mean score was 3.00, which could be classified in the fair category. There were 26 students ( $90 \%$ of the students) who got scores included in the fair category. 3 students (10\% of the students) got scores included in the poor category. It was noticed that there were no students who were classified in the very good, good, and very poor categories.

Next in terms of the mechanic, the mean score was 2.61, which could be classified in the fair category. There were 18 students (62\% of the students) who got scores included in the fair category. 11 students (38\% of the students) got scores included in the poor category. It was noticed that there were not any students who were included in the very good, good, and very poor categories.

In addition to knowing the students' last scores, it was obligatory also to anatomize the learners' products from stage to stage of the process approach. In general, the learners followed all the stages of the process approach. It implies that they did prewriting, drafting, revising, and editing.

In conclusion in Cycle I, based on the score of the students' final product the result of the application of the action had fulfilled the criteria of success. There were more than $50 \%$ of the learners who achieved a score above the minimum passing grade; there were 19 learners $(65.5 \%)$. With the design of Classroom Action Research implemented in this research, in terms of the students' final products, the criteria of success had been reached within a single cycle. Also, the result of Cycle I had been answered the research problem of this study. However, the researcher decided to conduct Cycle II to avoid coincidence and to identify the following influence after the first cycle was conducted.

\section{Overall Findings in Cycle I}

The overall findings will summarize the results of the activities in cycle 1 . This cycle can be concluded that the research has met the 3 specified success criteria. It can be seen from the results of data analysis on student participation in the teaching and learning process, student outcomes, and student responses to the application of the process approach obtained from observation checklists, field notes, and questionnaires. 
The first criteria (mention the criterion) stated that $70 \%$ of the students or more got engaged in the teaching and learning process. The data analysis confirmed that 14 activities (70\%) did at minimum $64.3 \%$ of the activities ( 9 activities) listed in the observation checklist. Concerning the second criteria of success which stated that at minimum $50 \%$ of the learners achieved a score equal to or more than 60 , the finding showed that $65 \%$ of the students already achieved a score of 60 or more. It meant that the second criterion was met. The last criterion 'at least $70 \%$ of the learners' good response to the application of the process approach in writing procedure texts' was met finding exhibited that the percentage of the students who showed good responses. To be exact, the minimum percentage of the students' responses was $48.27 \%$ and maximum percentage of the students' responses was $96.55 \%$, and the mean of the students' responses was $82 \%$. It means that the last criterion was met.

In short, because of the findings of the research that had already fulfilled the criteria of success decided but the observation checklist had not met. The researcher and collaborator were decided to next cycle. Nevertheless, to assure that the improvement made by the students in their writing abilities was due to the application of the process approach in writing procedure texts.

Table 6 The Description of the Criteria of Success and the Finding of the Study

\begin{tabular}{|c|c|c|c|}
\hline No & Criteria of Success & Finding of the Study & Note \\
\hline 1 & $\begin{array}{l}70 \% \text { of the students or more } \\
\text { participated in the teaching- } \\
\text { learning process }\end{array}$ & $\begin{array}{l}9 \text { activities out of } 14 \text { activities } \\
(64.3 \%) \text { in the teaching and } \\
\text { learning process by doing at } \\
\text { minimum } 9 \text { activities listed in the } \\
\text { observation checklist. }\end{array}$ & $\begin{array}{l}\text { The criterion } \\
\text { was not met }\end{array}$ \\
\hline 2 & $\begin{array}{l}\text { At least } 50 \% \text { of the students' } \\
\text { final products obtained a } \\
\text { final score equal to or more } \\
\text { than } 60 \text { in the analytic } \\
\text { scoring rubric. }\end{array}$ & $\begin{array}{l}65.5 \% \text { of the students final } \\
\text { products already achieved scores } \\
\text { equal to or more than } 60 .\end{array}$ & $\begin{array}{l}\text { The criterion } \\
\text { was met }\end{array}$ \\
\hline 3 & $\begin{array}{l}70 \% \text { of the learners or more } \\
\text { had good responses to the } \\
\text { implementation of the } \\
\text { process approach for their } \\
\text { writing class. }\end{array}$ & $\begin{array}{l}\text { At least } 82 \% \text { of the students have } \\
\text { positive reactions to the } \\
\text { application of the process } \\
\text { approach }\end{array}$ & $\begin{array}{l}\text { The criterion } \\
\text { was met }\end{array}$ \\
\hline
\end{tabular}

\section{Research Findings of Cycle II}

The second cycle was done in three meetings. The number of students was 29 students of the first graders in this school. At the end of Cycle II, the researcher found the most salient significant finding that students' awareness of the writing process increased through the process approach. It was indicated by the fact that the students' involvement during the process of writing which employed the process approach was high. The results of the observation of the students' involvement showed a good level. The students' involvement increased from $64.3 \%$ to $78 \%$. The details of students who participated in every phase of the process approach in Cycle II

The yield of the observation of learners' participation in Cycle II indicated that the learners' involvement during the writing process reached a good level. Twenty-nine students were involved in activities at each stage of the process approach (prewriting, drafting, revising, and editing) with a percentage of $78 \%$ (11 out of 14 activities). 
Table 7 The Students' Participation in Each Stage of the Process Approach

\begin{tabular}{|c|c|c|c|c|}
\hline No & $\begin{array}{c}\text { Instructional } \\
\text { Process }\end{array}$ & Number Activities & $\begin{array}{l}\text { The activity is } \\
\text { done (Yes) }\end{array}$ & $\begin{array}{l}\text { The activity is } \\
\text { not done (No) }\end{array}$ \\
\hline \multirow[t]{7}{*}{1} & Prewriting & Answering the teacher's questions. & $\sqrt{ }$ & \multirow{7}{*}{$\sqrt{ }$} \\
\hline & & Discussing with their groups. & $\sqrt{ }$ & \\
\hline & & $\begin{array}{l}\text { Paying attention to a model of procedure } \\
\text { texts. }\end{array}$ & $\sqrt{ }$ & \\
\hline & & $\begin{array}{l}\text { Exploring their ideas, order ideas for the } \\
\text { initial draft. }\end{array}$ & & \\
\hline & Drafting & Writing title, ingredients, and steps. & $\sqrt{ }$ & \\
\hline & & $\begin{array}{l}\text { Making sentences and arranging them in } \\
\text { a rough draft based on the instruction. }\end{array}$ & $\sqrt{ }$ & \\
\hline & & Writing their first draft. & $\sqrt{ }$ & \\
\hline \multirow[t]{4}{*}{2} & Revising & Working in groups & $\sqrt{ }$ & \multirow{8}{*}{$\sqrt{ }$} \\
\hline & & $\begin{array}{l}\text { Revising their draft based on guidelines } \\
\text { of revising. }\end{array}$ & $\sqrt{ }$ & \\
\hline & & Revising their classmates' draft. & $\sqrt{ }$ & \\
\hline & & Discussing with the peer and the teacher. & & \\
\hline \multirow[t]{4}{*}{3} & Editing & Rewriting a greater draft based on the & $\sqrt{ }$ & \\
\hline & & classmates. & & \\
\hline & & $\begin{array}{l}\text { Exchanging their revised draft with their } \\
\text { peers. }\end{array}$ & $\sqrt{ }$ & \\
\hline & & $\begin{array}{l}\text { Editing the grammar, spelling, } \\
\text { punctuation, and capitalization based on } \\
\text { the guidelines of editing. }\end{array}$ & & \\
\hline
\end{tabular}

The yield of the observation of learners' participation in Cycle II showed that the learners' involvement during the writing process reached a good level. Twenty-nine students have been involved in activities in each stage of the process approach (prewriting, drafting, revising, and editing) with a percentage of $78 \%$ (11 of 14 activities).

To sum up, the yield of the data analysis indicated that the learners' participation in the teaching and learning process has already met the criteria of success determined in that $70 \%$. The students could do the activities listed in the observation checklist $78 \%$.

As in Cycle I, the data on the learners' last products were gained from the learners' final writing. The data, then, were analyzed by 2 raters utilizing the analytic scoring rubric determined. Then to get the students' final scores, students' scores from the 2 raters were summed up and divided by 2 (See Appendix 1).

The yield of the analysis indicates that $96 \%$ of the learners (28 students out of 29) obtained a score equal to or greater than 60. The score ranges from 59-70 in terms of aspects of writing. The result of data analysis at the stage shows that the students' average scores in each aspect of writing are better than their scores in Cycle I. Among the 5 aspects of writing, the details of students' score distribution in terms of content, organization, vocabulary, grammar, and mechanics could be seen in Figure 1 and Table 2 below. The tables depict the improvement the students made in each aspect of writing at Cycle II. 
The Students' Average score of Every Facet of Writing in Cycle I and Cycle I

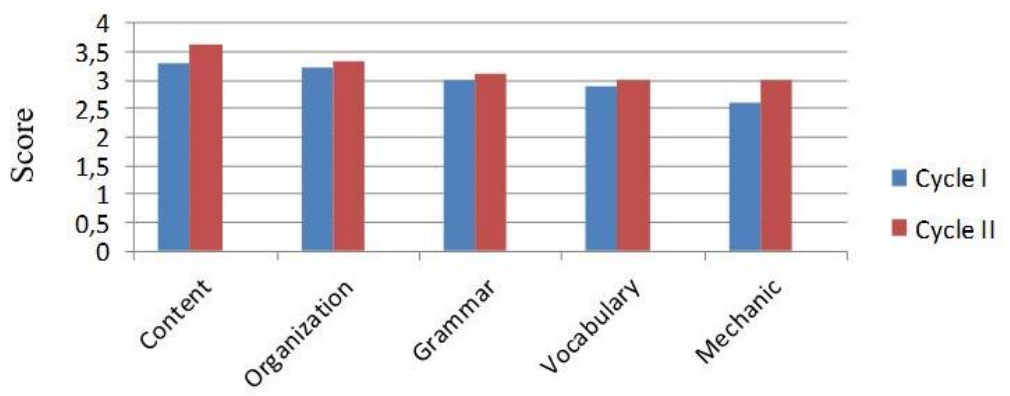

Aspects of writing

Figure 1 The learners' Average score of Every Facet of Writing in Cycle I and Cycle II

With Figure 1, it is evident that in terms of content, the average score improved from 3.18 in Cycle I to 3.64 in Cycle II. Regarding organization, the students improved from 3.07 to 3.33. For grammar, the students improved 3.00 to 3.36. It means that the average scores of students are in progress. On vocabulary, the score increase from 2.92 to 3.02. In the last aspect, mechanics, the score increased from 2.61 to 3.02 .

Table 8 The Students Score Distribution in terms of Content, Organization, Vocabulary, Grammar, and Mechanic

\begin{tabular}{|c|c|c|c|c|c|c|c|c|c|c|}
\hline $\begin{array}{l}\text { Writing } \\
\text { Aspect }\end{array}$ & Conten & & Organi & ation & Vocabu & $\operatorname{ary}$ & Gramm & & Mechar & \\
\hline Category & $\begin{array}{l}\text { Distri } \\
\text { bution }\end{array}$ & $\begin{array}{l}\text { Perc } \\
\text { enta } \\
\text { ge }\end{array}$ & $\begin{array}{l}\text { Distri } \\
\text { bution }\end{array}$ & $\begin{array}{l}\text { Perc } \\
\text { enta } \\
\text { ge }\end{array}$ & $\begin{array}{l}\text { Distrib } \\
\text { ution }\end{array}$ & $\begin{array}{l}\text { Perc } \\
\text { enta } \\
\text { ge }\end{array}$ & $\begin{array}{l}\text { Distrib } \\
\text { ution }\end{array}$ & $\begin{array}{l}\text { Per } \\
\text { cent } \\
\text { age }\end{array}$ & $\begin{array}{l}\text { Distri } \\
\text { bution }\end{array}$ & $\begin{array}{l}\text { Perce } \\
\text { ntage }\end{array}$ \\
\hline $\begin{array}{l}\text { Very } \\
\text { good }\end{array}$ & 0 & $0 \%$ & 0 & $0 \%$ & 0 & $0 \%$ & 0 & $0 \%$ & 0 & $0 \%$ \\
\hline Good & 15 & $52 \%$ & 9 & $31 \%$ & 1 & $\begin{array}{l}3.5 \\
\%\end{array}$ & 3 & $\begin{array}{l}10 \\
\%\end{array}$ & 3 & $10 \%$ \\
\hline Fair & 14 & $48 \%$ & 20 & $69 \%$ & 27 & $93 \%$ & 26 & $\begin{array}{l}90 \\
\%\end{array}$ & 24 & $83 \%$ \\
\hline Poor & 0 & $0 \%$ & 0 & $0 \%$ & 1 & $\begin{array}{l}3.5 \\
\%\end{array}$ & 0 & $0 \%$ & 2 & $7.0 \%$ \\
\hline Very poor & 0 & $0 \%$ & 0 & $0 \%$ & 0 & $0 \%$ & 0 & $0 \%$ & 0 & $0 \%$ \\
\hline Total & 29 & $\begin{array}{l}100 \\
\%\end{array}$ & 29 & $\begin{array}{l}100 \\
\%\end{array}$ & 29 & $\begin{array}{l}100 \\
\%\end{array}$ & 0 & $\begin{array}{l}100 \\
\%\end{array}$ & 29 & $100 \%$ \\
\hline
\end{tabular}

Based on Table 8, in terms of content, there were 15 students $(52 \%)$ who got scores in the good category. Fourteen students (48\% of the students) got scores included in the fair category. It was noticed that no student was included in the very good, poor, and very poor category.

In terms of organization, there were 9 students $(31 \%)$ who obtained scores in the good category. Twenty learners $(69 \%)$ obtained scores included in the fair category. It was noticed that no student was included in the very good, poor, and very poor category. Too short as a paragraph, the number of the minimum sentence is 4 .

Next, in terms of vocabulary, one student $(3.5 \%)$ got scores in the good category. Twenty-seven students ( $93 \%$ of the students) got scores included in the fair category. One student (3.5\%) got a score 
included in the poor category. It was noticed that no student was included in the very good, and very poor categories. Too short as a paragraph

In terms of grammar, no student obtained scores in the very good, $3(10 \%)$ obtained scores included in the good category. twenty-six learners $(90 \%)$ obtained scores included in the fair category. It was noticed that no student was included in the poor and very poor categories.

In the last terms of the mechanic, no student obtained scores in the very good, 3 learners (10\%) obtained scores included in the good category. Twenty-four students $(83 \%)$ obtained scores included in the fair category. Two learners $(7.0 \%)$ got scores included in the poor category. It was noticed that there were not any students who were included in the very poor category.

In addition to analyzing the students' final product to obtain scores, it was obligatory also to anatomize the learners' results from stage to stage of process approach in writing. At the prewriting stage, the students generate ideas, after that, they revised their draft about content and organization. The last stage the learners went through was editing. The students mostly edited grammar, especially the verb, and ignored other aspects, such as punctuation and capitalization as result in their final products. To identify, the significance of Cycle II, it is important to pay attention to students' mean scores in the preliminary study, in Cycle I, and Cycle II can be provided in Figure 2.

In conclusion, based on the score distribution of the learners' final product in Cycle II, the result of the application of the action reached also the criteria of success. In the preliminary study, 27 students $(93 \%)$ achieved a score under the minimum passing grade. 2 students $(6.9 \%)$ got scores equal to the minimum passing grade. In Cycle I, 19 students $(65.5 \%)$ got scores above the minimum passing grade but needed improving. 10 students $(34 \%)$ who achieve the score under the minimum passing grade. In Cycle II, 28 students (96\%) got a score above the minimum passing grade. Also, the result of cycle II had answered the research problem of this study.

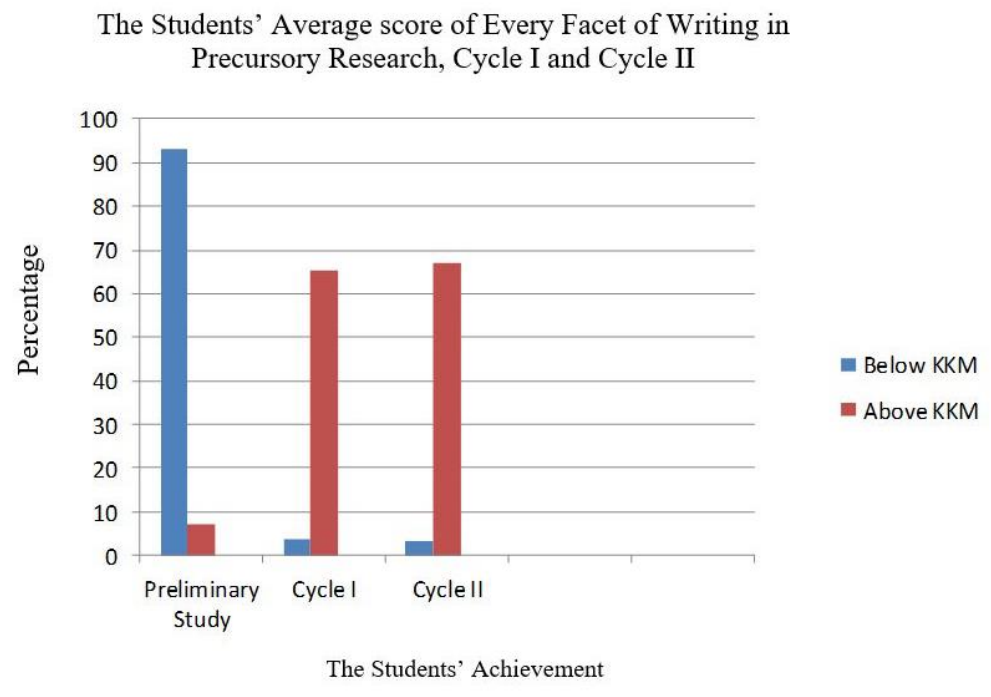

Figure 2 The Learners' Average score of Writing in the Precursory Research, Cycle I, Cycle 2

In brief, since the criterion of success either in terms of the product had been achieved in Cycle I or Cycle II, the investigator determined to quit the cycle in this research. 


\section{Overall Findings of the Study}

This action research is intended to improve the ability to write procedural texts of first graders through a process approach. Therefore, it can interfere that the learners' competence to write procedure texts was effectively rectified. See comment 31 about paragraphs.

About criteria number 1 that cared about the student's inclusion in the teaching and learning process, the instruments employed were observation checklist and field notes. The yield of the data analysis showed that there were $70 \%$ of the learners did at minimum 10 activities listed in the observation checklist. It implies that the criterion was fulfilled since it declared that the research was contemplated successful if there were $70 \%$ of the learners took part in the teaching and learning process.

The second criteria shaded with the learners' scores for the last results. The criterion declared that $50 \%$ of the learners or more ought to reach a score of at a minimum of 60 . The yield of the data analysis of the learners' product in Cycle I showed that $65 \%$ of the learners already gained the determined score.

Moreover, in Cycle II, there was more percentage of the learners obtaining a score of at least 60. The exact percentage was $96 \%$. From the 2 data analysis result in Cycle I and Cycle II, in addition to the refinement of the learners' scores, about each aspect of writing, the students also made progress from the precursory research to Cycle II. Figure 3 shows the students' improvement in every facet of writing in the precursory research, in Cycle I and Cycle II.

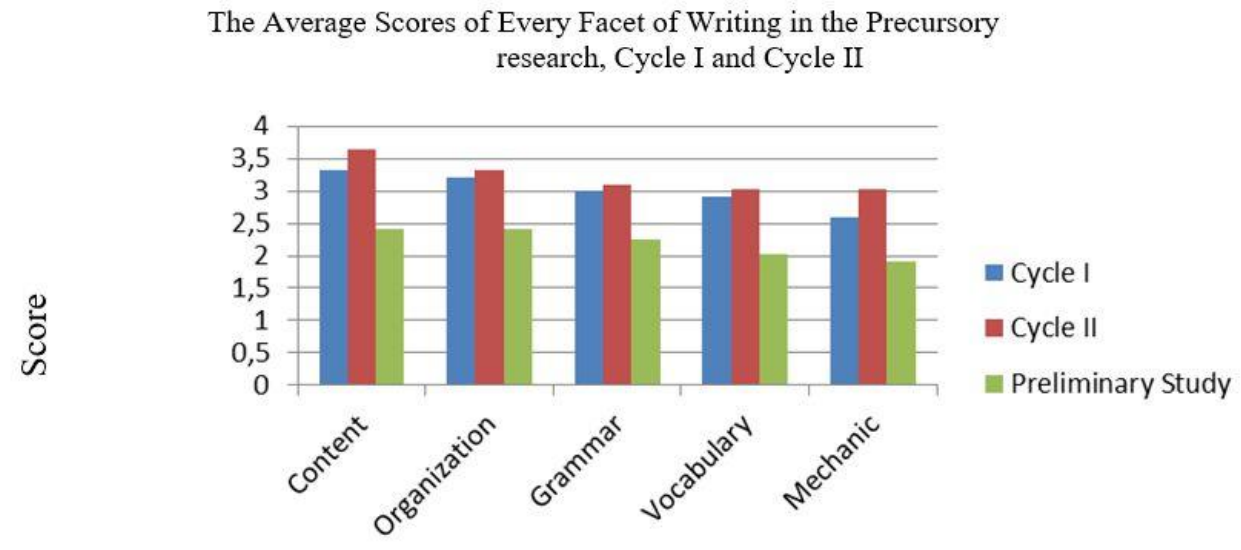

\section{Aspects of writing}

Figure 3 The Average Scores of Every Facet of Writing in the Precursory Research, Cycle I and Cycle II

The last criterion of success that was on the learners' reactions to the application of the process approach in writing procedure texts in their class stated $70 \%$ of the learners or more should have the right reactions to the application of this process. The instrument used was the questionnaire. The yield of the data analysis proved that the learners' reactions to every declaration were splendid since the minimum percentage of the students who chose the preferred options was $96 \%$. It implies that the research already fulfilled the criterion of success decided.

Overall the percentage, of the learners reaching the score above minimum passing grade had improved from $6.9 \%$ ( 2 students) in the preliminary study to $65.5 \%$ (19 students) in Cycle I and $96 \%$ 
(28 students). Besides, the mean score of every facet of the students' writing test. About content, the mean score increases from 2.14 in the precursory research to 3.18 in Cycle I and 3.64 at the Cycle II,

In terms of organization, the mean score upgraded from 2.41 in the precursory research to 3.07 in Cycle I and 3.33 at Cycle II. Next in terms of vocabulary, the mean score increased from 2.03 in the precursory research to 2.92 in Cycle I and 3.02 in Cycle II, and next in terms of grammar, the mean score increased from 2.24 in the precursory research to 3.00 in Cycle I and to 3.36 at the Cycle II. In the last term of the mechanic, the mean score increased from 1.90 in the precursory research to 2.61 in Cycle I and 3.02 at Cycle II.

In conclusion, with the score distribution of the learners' final products at Cycle II, the yield of the implementation of the action has also met the criteria of success. There were more than $50 \%$ of the learners who achieved the score minimum passing degree there were 28 students above 60 also. The yield of Cycle II had responded to the research matter of this research. In brief, since the criteria of success either in terms of the products had been achieved in Cycle I or at Cycle II, the investigator and collaborator determined to stop the study.

It implies that the research already fulfilled the criterion of success decided. The details of students' scores in the precursory research, Cycle I, and Cycle II could be provided in Table 9 below.

Table 9 The Students Score in Precursory Study, Cycle I, and Cycle II

\begin{tabular}{llll}
\hline Statistic & Precursory Research & Cycle I & Cycle II \\
\hline Minimum score & 36.00 & 54.00 & 59.00 \\
Maximum score & 64.00 & 66.00 & 72.00 \\
Mean score & 45.00 & 61.00 & 65.00 \\
Standard Deviation & 6.03 & 3.14 & 2.89 \\
\hline
\end{tabular}

In terms of minimum score increased from 36.00 in the precursory research to 54.00 in Cycle I and to 59.00 in Cycle II. In terms of maximum score increased from 64.00 in the precursory research to 66.00 in Cycle I and to 72.00 in Cycle II. The next terms of mean upgraded from 45.00 in the precursory research to 61.00 in Cycle I and 65.00 in Cycle II. The last term of standard deviation decreased from 6.03 in precursory research to 2.08 in Cycle I, and 2.82 in Cycle II, which means that learners' writing scores from the precursory, Cycle I, and Cycle II become more homogeneous.

Before the application of the action, it looks that the learners' writing products were exactly low; i.e. most of the learners (93\%) obtained scores below passing grade, only 2 students or $7.0 \%$ (2 students out of 29 students) who obtained 60 in the precursory research. The competence to compose correctly is not a gained skill; it is generally studied as an assembly of practices in a formal teaching and learning setting in the classroom. Writing skills have to be practiced and learned through the process. The process approach can simplify the necessity of great writers. Writing procedure texts engages writing competencies that means the competence either to relate or retell each of data in form of logical occasions into written text. In resulting procedure texts, learners have to be mindful of the part of characteristics or structures that put up the texts and social purposes too.

They are prewriting, drafting, revising, and editing. To the schemes above, it is quite evident that basically, the process approach is composed of 4 stages, namely, prewriting, drafting, revising, and editing. 
With previous research, the use of the process approach in straightening the competence of students in writing texts carried out by Faraj (2015), it was found that the process approach was able to improve the competence of students in writing and the active involvement of students. However, the cyclic process done by Megawati \& Anugerahwati (2012) consisted of three cycles whereas the present study had two cycles. Besides, this present study also applies procedure texts whereas the previous study implements recount texts.

In conclusion, the results of the analysis above indicated the process approach could be improved learners' competence in writing procedure texts. It could improve learners' writing. It could be said that the application of the process approach was successful in rectifying students' competence in writing procedure texts at the first grade of this school.

\section{CONCLUSIONS}

With the study findings and discussions of the research, it could be concluded that the skill of writing procedure texts of the first graders of this school could be improved through the process approach. The process approach looks to be the most successful manner of teaching writing in procedure texts.

In addition, the yield of the data analysis indicates that the process approach is effective in rectifying the competence in writing procedure texts of the first graders of this school. The success has been indicated by the attainment of the two criteria of success that cared with the learners' inclusion in the teaching and learning process and the learners' scores for their last results.

Hereinafter, there were a lot of positive impacts in the application of this approach that result in the learners' good attainment in the application of this approach that results in the learners' good attainment in writing procedure text. Among others were: the learners were able to produce ideas in prewriting activities. They were able to investigate, choose, and instruct thoughts for writing, they were able to write their rude drafts from the thoughts they obtained in the prewriting activities, they were able to create the rude drafts preferable ones as there was an opportunity for them to revise they were able to alter, append, or eliminate everything in it and they were able to verify the righteousness of the grammar and mechanics of the drafts which were able to be employed personally or in pairs.

The weakness in this study is spending a lot of time doing a lot of stages to do, preparing all the teachers' pieces of equipment to do, and wasting too much time to do for every cycle needed. For further researchers, based on the effectiveness of the implementation of the process approach in teaching writing, English researchers are recommended to employ this as an alternative strategy.

\section{REFERENCES}

Alfaki, I. M., \& الفكى الفى , '. (2015). University Students' English Writing Problems: Diagnosis and Remedy. http://dglib.nilevalley.edu.sd:8080/xmlui/handle/123456789/2116

Biber, D., Gray, B., \& Poonpon, K. (2011). Should We Use Characteristics of Conversation to Measure Grammatical Complexity in L2 Writing Development? TESOL Quarterly, 45(1), 535. https://doi.org/10.5054/tq.2011.244483 
Biggam, J. (2018). EBOOK: Succeeding with your Master's Dissertation: A Step-by-Step Handbook: Step-by-step Handbook. McGraw-Hill Education (UK).

Duijnhouwer, H., Prins, F. J., \& Stokking, K. M. (2012). Feedback providing improvement strategies and reflection on feedback use: Effects on students' writing motivation, process, and performance. Learning and Instruction, 22(3), 171-184. https://doi.org/10.1016/j.learninstruc.2011.10.003

Hosni, S. A. (2014). Speaking Difficulties Encountered by Young EFL Learners. International Journal on Studies in English Language and Literature, 9.

Kirkpatrick, A., \& Sussex, R. (Eds.). (2012). English as an International Language in Asia: Implications for Language Education (Vol. 1). Springer Netherlands. https://doi.org/10.1007/978-94-007-4578-0

Lam, R. (2010). A Peer Review Training Workshop: Coaching Students to Give and Evaluate Peer Feedback. TESL Canada Journal, 114-114. https://doi.org/10.18806/tesl.v27i2.1052

Ltd, I.-I. B. (2013). In the Importance of EFL Learners' writing Skill: Is there any Relation between Writing Skill and Content Score of English Essay Test? International Letters of Social and Humanistic Sciences, 06, 1-12.

Mattarima, K., \& Hamdan, A. R. (2011). The Teaching Constraints of English as a Foreign Language in Indonesia: The Context of School-Based Curriculum. SOSIOHUMANIKA, 4(2), Article 2. https://doi.org/10.2121/sosiohumanika.v4i2.452

Megawati, F., \& Anugerahwati, M. (2012). Comic Strips: A Study on the Teaching of Writing Narrative Texts to Indonesian EFL Students. TEFLIN Journal, 23(2), 183-205. https://doi.org/10.15639/teflinjournal.v23i2/183-205

Mustafa, F., Kirana, M., \& Bahri Ys, S. (2016). Errors in EFL writing by junior high students in Indonesia. International Journal of Research Studies in Language Learning, 5(5). https://doi.org/10.5861/ijrsll.2016.1366

Ouellette, G., Sénéchal, M., \& Haley, A. (2013). Guiding Children's Invented Spellings: A Gateway Into Literacy Learning. The Journal of Experimental Education, 81(2), 261-279. https://doi.org/10.1080/00220973.2012.699903

Palloff, R. M., \& Pratt, K. (2013). Lessons from the Virtual Classroom: The Realities of Online Teaching. John Wiley \& Sons.

Ratnaningsih, E. (2016). Improving Students' Writing Ability through the Use of Dictogloss Technique. Transformatika: Jurnal Bahasa, Sastra, dan Pengajarannya, 12(2), 1-14. https://doi.org/10.31002/transformatika.v12i2.186

Roy-Campbell, Z. M. (2015). Teaching English as a ГÇÿSecond LanguageГÇÖ In Kenya and the United States: Convergences and Divergences. Global Education Review, 2(2). Retrieved from https://ger.mercy.edu/index.php/ger/article/view/103 
Savignon, S. J. (2017). Communicative Competence. TESOL Encyclopedia of English Language Teaching (pp. 1-7). American Cancer Society. https://doi.org/10.1002/9781118784235.eelt0047

Shehadeh, A. (2011). Effects and student perceptions of collaborative writing in L2. Journal of Second Language Writing, 20(4), 286-305. https://doi.org/10.1016/j.jslw.2011.05.010

Zaid, M. A. (2011). Effects of web-based pre-writing activities on college EFL students' writing performance and their writing apprehension. Journal of King Saud University - Languages and Translation, 23(2), 77-85. https://doi.org/10.1016/j.jksult.2011.04.003 


\section{APPENDIX 1}

The Students' Final Scores in Cycle II obtained from Rater 1 and Rater 2

\begin{tabular}{|c|c|c|c|c|c|}
\hline No & Rater 1 & Rater 2 & Total & $\mathbf{Y}$ & Succeed \\
\hline 1 & 60 & 66 & 126 & 63 & Yes \\
\hline 2 & 66 & 66 & 132 & 66 & Yes \\
\hline 3 & 66 & 64 & 130 & 65 & Yes \\
\hline 4 & 66 & 66 & 132 & 66 & Yes \\
\hline 5 & 66 & 70 & 136 & 68 & Yes \\
\hline 6 & 60 & 66 & 126 & 63 & Yes \\
\hline 7 & 60 & 66 & 126 & 63 & Yes \\
\hline 8 & 70 & 66 & 136 & 68 & Yes \\
\hline 9 & 66 & 60 & 126 & 63 & Yes \\
\hline 10 & 66 & 66 & 132 & 66 & Yes \\
\hline 11 & 64 & 62 & 126 & 63 & Yes \\
\hline 12 & 70 & 66 & 136 & 68 & Yes \\
\hline 13 & 60 & 60 & 120 & 60 & Yes \\
\hline 14 & 70 & 68 & 138 & 69 & Yes \\
\hline 15 & 70 & 64 & 134 & 67 & Yes \\
\hline 16 & 74 & 66 & 140 & 70 & Yes \\
\hline 17 & 68 & 64 & 132 & 66 & Yes \\
\hline 18 & 74 & 58 & 132 & 66 & Yes \\
\hline 19 & 70 & 70 & 140 & 70 & Yes \\
\hline 20 & 60 & 70 & 130 & 65 & Yes \\
\hline 21 & 64 & 70 & 134 & 67 & Yes \\
\hline 22 & 74 & 70 & 144 & 72 & Yes \\
\hline 23 & 60 & 66 & 126 & 63 & Yes \\
\hline 24 & 62 & 70 & 132 & 66 & Yes \\
\hline 25 & 70 & 66 & 136 & 68 & Yes \\
\hline 26 & 60 & 66 & 126 & 63 & Yes \\
\hline 27 & 66 & 64 & 130 & 65 & Yes \\
\hline 28 & 66 & 66 & 132 & 66 & Yes \\
\hline 29 & 60 & 58 & 118 & 59 & No \\
\hline Total & 1908 & 1900 & 3808 & 1904 & \\
\hline Average & 65.79 & 65.52 & 131.31 & 65.66 & \\
\hline
\end{tabular}

